\title{
STRATEGI KOMUNIKASI PEMERINTAHAN DI MASA UMAR IBN AL-KHATTAB
}

\author{
Oleh : Nurlaelah Abbas \\ Dosen Jurusan Jurnalistik Fakultas Dakwah dan Komunikasi UIN \\ Alauddin Makassar \\ Email : nurlaelahabbas@gmail.com
}

\begin{abstract}
Abstrak
Penelitian ini mendeskripsikan perkembangan pemerintahan Khalifah Umar Ibn Al-Khattab. Secara khusus, penelitian ini ingin menggambarkan situasi komunikasi pemerintahan dan strategi komunikasi kepemimpinan Umar. Salah satu gambaran dari pemerintahan ini yaitu pembinaan masyarakat secara islam yang dibentuk dengan menggunakan pola pendekatan komunikasi antarpribadi.
\end{abstract}

\section{Keyword :}

Komunikasi pemerintahan, pengembangan masyarakat

\section{A. PENDAHULUAN}

Kebangkitan dan perkembangan Islam dari masa ke masa, ditentukan oleh sistim pemerintahan yang diperankan oleh penentu kebijakan. Salah satu contoh tercatat dalam sejarah adalah Khalifah Umar bin Khattab ${ }^{1}$ salah satu dari Khulafa al-Rasyidin dan sahabat Nabi yang sangat dibanggakan karena keberanian, ketegasan sikap dan kejujuran dan keadilannya dalam melihat setiap persoalan, baik menyangkut pribadi dan keluarganya maupun secara keumatan dari berbagai aspek kehidupan.

Umar bin Khattab jauh sebelum menjabat khalifah, dia selalu memberi pertimbangan kepada Rasulullah dalam beberapa persoalan, bahkan tidak jarang wahyu turun memperkuat pandangan-pandangannya. Misalnya; dalam peristiwa Perang Badar. Setelah perang terjadi, Rasulullah musyawarah dengan sahabatnya tentang apa yang mesti dilakukan terhadap tawanan perang. Umar mengusulkan agar semua tawanan "di bunuh", sedang Abu Bakar mengusulkan agar mereka "membayar tebusan". Dalam hal tersebut, Rasulullah menerima pendapat Abu Bakar. Maka Allah menurunkan wahyu yang menguatkan usulan Umar dan mencela apa yang dilakukan oleh Nabi. ${ }^{2}$

\footnotetext{
${ }^{1}$ Nama lengkapnya, Umar bin Khattab bin Nufail bin Abdul 'Uzza bin Rabah bin Qurt bin Razah bin Ady bin Ka'ab bin Luay. Amirul Mukminin, Abu Hafash al-Quraisy, al-Adawi, al-Faruq. Ibu Umar bernama Hantamah binti Hasyim. Lihat Hafidz Jalaluddin al-Suyuty, Tarikh al-Khulafa, diterjemahkan oleh Samson Rahman dengan judul Tarikh Khulafa Sejarah Para Penguasa Islam, cet. 4 ( Jakara : Pustaka al-Kautsar, h. (Beirut-Lubnan : Dar al-Fikr, t.th), h. 120 Lihat juga Dewan Ensiklopedi Islam, Ensiklopedi Islam, jilid 5, cet.9 ( Jakarta : Ichtiar Baru Van Houve, 2001), h. 124.

${ }^{2}$ Ahmad al-Usairy, al-Tarikh al-Islamiy, diterjemahkan oleh Samson Rahman dengan judul Sejarah Islam Sejak Zaman Nabi Adam Hingga Abad XX, cet.6 (Jakarta : Media Eka Sarana, 1429 H/2008 M), h, 154
} 
Peranan Umar yang begitu menonjol tentu bukan hanya dilihat dari satu sudut pandang saja, akan tetapi ditentukan oleh sistim kebijakan dan dinamika berpikir yang cenderung mengutamakan musyawarah, juga dalam sistim politik mengendalikan pemerintahan serta hubungan dengan pihak luar, terbukti dengan usaha ekspansi yang telah dilakukannya.

Dalam hal keberanian tercatat bahwa semua peperangan yang dipimpin oleh beliau, tidak pernah ketinggalan dan Umar senantiasa siap membela dan melindungi Rasulullah dari bahaya yang mengancamnya. Oleh karena itu, wajar kalau Rasulullah saw pernah berdoa' kepada Allah "Ya Allah, muliakanlah agama Islam ini dengan Umar bin Khattab". 3

Beberapa tindakan dan cerminan keperibadian Umar bin Khattab yang tercatat dalam sejarah bahkan didukung oleh nas al-Qur'an dan Hadis. Hal inilah yang menjadikan penulis untuk melakukan kajian dan pemahaman selanjutnya.

\section{RUMUSAN MASALAH}

1. Bagaimana situasi politik sebelum dan awal masa pemerintahan Umar bin Khattab?

2. Bagaimana strategi komunikasi pemerintahan pada masa Umar bin Kharttab ?

\section{B. PEMBAHASAN}

\section{Kondisi Masyarakat dan Negara Sebelum Umar bin Khattab}

\section{a. Masa Rasulullah saw}

Zaman Islam pertama dikenal al-'Asr al-Nubuwah yang dibagi kepada dua zaman yang berbeda sejarahnya. Zaman pertama disebut al-'Ahd al-Makki (zaman Mekah) dan kedua, al-'Ahd al-Madani (zaman Madinah). Priode pertama dihabiskan oleh beliau di Mekah sejak dilantik menjadi Rasulullah sampai berhijrah ke Madinah yaitu ketika beliau menumpukkan masanya kepada perundangan al-Qur'an dan perundangan Rasulullah. Pada waktu itu beliau berusaha untuk membenarkan konsep dan ide masyarakat disekitarnya demi mensucikan jiwa, mensejahterakan pemikiran dan mencoba menghapuskan perlakuan-perlakuan jahiliyah dari hati mereka agar dapat bersama-sama menyembah Allah SWT.

Pada zaman ini, tidak ada perintah al-Qur'an dan Hadis yang menyebutkan semacam perundangan yang memerlukan pelaksanaan kecuali yang dikaitkan khusus dengan hal-hal yang berkaiatan tentang kepercayaan, seperti larangan memakan binatang-binatang yang disembelih tanpa menyebut nama Allah sebagaimana yang disebutkan dalam Q.S al-An'am (6) : 21, atau tentang hal-hal yang berkaitan dengan pemujaan yang menghubungkan orang Islam kepada Allah dan menyuruh mereka berbuat kebaikan, seperti diterangkan dalam Q.S al-'Ankabut (29) : $45 .{ }^{4}$

\footnotetext{
${ }^{3}$ Ahmad Syalabiy, Mausu'ah al-Tarikh al-Islamiy wa al-Hadarah al-Islamiyah, juz I (al-Qahira : Makatabah al-nahdah al-Misriyah, 1984), h. 570.

${ }^{4}$ Muhamed S. El-Awa, On the Political System of the Islamic State, diterjemahkan oleh Mohd Isa Che Dir, dengan judul Sistim Politik Negara Islam, (Kuala Lumpur : Dewan Pustakan dan Bahasa, 1991), h. 14.
} 
Ciri-ciri zaman ini adalah mengikuti pendekatan al-Qur'an, terutama dalam menyatakan pertikaian yang ditunjukkan oleh musuh-musuh kepada kaum Muslimin. Pada zaman ini pula, al-Qur'an tidak memberi penegasan tentang hal ihwal berperang ketika berada di Mekah, tetapi al-Qur'an menyeru umat Islam supaya bersabar dan bersikap pemaaf. Orang Islam hanya dibenarkan berperang pada detik akhir menjelang hijrah dari Mekkah. ${ }^{5}$

Pada priode Mekah, jumlah pengikut Nabi dari kaum Muslimin yang telah menerima agama baru yang dibawah oleh Rasulullah saw dan mempercayainya masih kurang. Oleh karena tidak mempunyai kawasan (areal) untuk pemimpin-pemimpin mereka mendirikan semacam bentuk kedaulatan atau kerajaan untuk mengamalkan ajaran-ajaran seperti yang dijelaskan dalam al-Qur'an, ia tidak melengkapi suatu ummah (masyarakat) bebas sebagai masyarakat Mekah keseluruhannya. Oleh karena itu Rasulullah sendiri yang mengembangkan agama baru ini (Islam)yang telah diamanahkan oleh Allah kepada-Nya. Aktivitas Rasulullah ditujukan kepada kelompok masyarakat disekelilingnya. ${ }^{6}$

Dengan demikian dapat dipahami bahwa, situasi dan kondisi masyarakat Islam priode awal di Mekah, tidak dapat membentuk suatu masyarakat atau organisasi politik dengan rujukan utamanya adalah al-Qur'an melalui Rasulullah, dan. Bagamanapun, ide untuk mempunyai wilayah selalu menjadi perhatian Rasulullah untuk tujuan dakwah (seruan) agar Islam dapat tumbuh dan berkembang.

Rasulullah berada di Mekah kurang lebih 13 tahun. beberapa orang dari Madinah membuat dua bai'ah yang menjadi dasar pendirian Negara Islam di Madinah. Bai'ah yang dimaksudkan adalah bai'ah al-Aqabah kedua ketika Rasulullah saw memohon supaya orang Ansar ber-iqrar mempercayai Allah dan Rasul-Nya serta mamatuhi kebenarannnya, memohon mereka agar supaya melindungi beliau sebagaimana mereka melindungi kaum wanita dan anak-anak mereka. .

Penghijrahan Rasulullah saw menandakan permulaan periode kedua yang dikenal sebagai al-'Ahd al-Madani (zaman Madinah). Setelah mengalami kesusahan dan tekanan kaum Quraisy selama di Mekah, Rasulullah diperintahkan untuk berhijrah. Yang menarik di sini ialah sebab penumpuan yang diberi terhadap zaman Madinah oleh pengkaji sejarah politik dan perundangan Islam adalah karena zaman ini banyak pelaksanaan perundangan di utarakan, dan akibat penghijrahan, negara Islam telah didirikan serta mendapat tempat dalam arena antarbangsa. Oleh karena itu, muncul keperluan untuk melaksanakan perundangan yang telah diturunkan melalui wahyu dalam bentuk yang paling sempurna untuk intarnal dan ekstarnal negara. ${ }^{8}$

\footnotetext{
${ }^{5}$ Syekh Muhammad Mustafah Syalabi, al-Madkhal fi al-Tarikh al-Ta'rif bi al-Fiqh al-Isami (Beirut : t.pt, 1968), h. 50-60.

${ }^{6}$ Muhamed S. El-Awa, op, cit, h. 14.

${ }^{7}$ Ibid

${ }^{8}$ Syekh Muhammad Mustafah, op, cit, h, 55
} 
Hijrahnya Nabi ke Madinah telah diawali oleh dua bai'ah al-'Aqabah. Dalam bai'ah pertama, Rasulullah bertemu dengan seorang laki-laki yang berikrar kepada beliau untuk mempercayai Tauhid (meng-Esakan Allah swt) dan untuk mengikuti moralitas yang menjadi dasar kemuliaan masyarakat. Di dalam bai'ah kedua, yang berlaku satu tahun kemudian, yaitu pada musim haji berikutnya, Rasulullah bertemu 73 orang laki-laki dan dua perempuan. Pada masa itu sebagai tambahan syarat-syarat bai'ah pertama bai'ah kedua menyangkut ikrar mereka untuk memberi dukungan keamanan juga masa perang untuk melawan musuh-musuh agama dan negara yang sedang direncanakan itu. Bai'ah ini juga termasuk kepatuhan sepenuhnya kepada kebenaran sebagai suatu keyakinan untuk menampakkan kebenaran. ${ }^{9}$

Oleh karena itu, dapat di katakan bahwa hijrah Rasulullah ke Madinah adalah merupakan hasil dari dua bai'ah tersebut, yang dianggap sebagai titik peralihan dalam sejarah Islam dan menjadi dasar atas berdirinya Negara Ialam. Dan di Madinahlah untuk pertama kali lahir satu komunitas Islam yang bebas dan merdeka di bawah pimpinan Nabi, dan terdiri dari pengikut Nabi yang datang dari Mekah (Muhajirin) dan penduduk Madinah yang telah memeluk Islam, serta yang telah mengundang Nabi untuk hijrah ke Madinah (Ansar). Tetapi umat Islam ketika itu bukan satu-satunya komunitas di Madinah. Di antara penduduk Madinah terdapat juga komunitaskomunitas lain yaitu orang-orang Yahudi dan sisa suku-suku Arab yang belum mau mernerima Islam dan masih tetap memuja berhala. Dengan kata lain, umat Islam di Madinah bagian dari suatu masyarakat yang majemuk. ${ }^{10}$ Dengan adanya bai'at atau MoU yang terjadi sebelum berhijrah, adalah menandakan adanya aturan-atuaran yang harus mengikat terutama dalam membela Negara dan bangsa.

Tidak lama setelah Nabi berada di Madinah, atau menurut sementara ahli sejarah belum cukup dua tahun dari kedatangan Nabi di kota itu, beliau mempermaklumkan satu piagam yang mengatur kehidupan dan hubungan antara komunitas-komunitas yang merupakan komponen-komponen masyarakat yang majemuk di Madinah. Piagam tersebut dikenal sebagai Piagam Madinah ${ }^{11}$.

Dengan adanya undang-undang Madinah yang dibuat oleh Rasulullah bersama kaum Yatsrib (kaum Anshar dan Muhajirin) dan kaum Yahudi adalah merupakan contoh dan pegangan sampai sekarang bagi kaum Muslimin yang hendak mendirikan Khilafah Islam atau Negara Islam ini.

\section{b. Masa Abu Bakar al-Siddiq}

Dengan wafatnya Rasulullah saw, tugas-tugas kekhalifahan dilaksanakan oleh pengganti beliau, Abu Bakar al-Siddiq setelah kaum Muslimin membaiatnya di

\footnotetext{
${ }^{9}$ Muhamed S. El-Awa, op, cit, h. 14.

${ }^{10}$ Munawir Sjadzali, Islam dan Tata Negara Ajaran, Sejarah dan Pemikiran, ed. 5 (Jakarta : Universitas Indonesia Press,,1993), h. 10.

${ }^{11}$ Ibid
} 
Madinah, di Saqifah Bani Sa'idah pada tahun 11 H (633 M.) Abu Bakar melindungi Islam dan memerangi orang-orang murtad (orang-orang yang keluar dari Islam) dan orang-orang yang tidak mau membayar zakat. Beliau mengokohkan tonggak-tonggak Islam di Semenanjung Arabia dan setelah itu mengarahkan tentara Islam ke Iraq dan Syam untuk menyebarluaskan agama. ${ }^{12}$

Pada masa pemerintahannya beliau banyak menyelesaikan persoalan dalam negeri terutama tantangan yang ditimbulkan oleh suku-suku bangsa Arab yang tidak mau tunduk lagi kepada pemerintah Madinah. Mereka menganggap bahwa perjanjian yang dibuat dengan Nabi Muhammad dengan sendirinya batal setelah Nabi wafat. Karena itu, mereka menentang Abu Bakar. Sikap keras kepala dan penentangan mereka dapat membahayakan agama dan pemerintahan. Sehingga Abu Bakar menyelesaikan persoalan ini dengan apa yang disebut dengan perang Riddah (perang melawan kemurtadan). Khalid bin al-Walid adalah Jenderal yang banyak berjasa dalam perang Riddah ini. ${ }^{13}$

Perbuatan mereka sebenarnya dianggap melawan hukum, sehingga Abu Bakar dengan tegas melancarkan operasi pembersihan terhadap mereka. Meskipun niat semula dimaksudkan sebagai tekanan untuk mengajak mereka kembali ke jalan yang benar, lalu berkembang menjadi perang merebut kemenangan. Tindakan pembersihan juga dilakukan untuk menumpas nabi-nabi palsu yang muncul ketika itu, demikian pula orang-orang yang enggan membayar zakat. ${ }^{14}$

Adapun kekuasaan yang dijalankan pada masa khalifah Abu Bakar, sebagaimana pada masa Rasulullah, bersifat senteral; kekuasaan legislatif, eksekutif, dan yudikatif terpusat di tangan khalifah. Selain menjalankan roda pemerintahan khalifah juga melaksanakan hukum, Meskipun demikian, seperti juga Nabi Muhammad, Abu Bakar selalu mengajak sahabat-sahabat besarnya bermusyawaah. ${ }^{15}$ Oleh karena itu, dalam pemerintahan Abu Bakar yang menonjol adalah "perang fisik" baik dalam lingkungan Madinah maupun di luar Madinah, karena mereka berpaling dari perjanjian semula yang telah dilakukan pada masa Rasulullah.

\section{Langkah dan usaha dalam menjalankan roda perpolitikan}

Seperti yang kita pahami bahwa, masa pemerintahan Umar bin Khattab adalah masa "perang dan ekspansi" ke beberapa kota dengan kemenangan yang selalu berpihak pada kaum Muslimin. Karena itu kedaulatan mereka secara otomatis meluas.

\footnotetext{
${ }^{12 ، A l i ~ H a f i d z, ~ F u s u l ~ m i n ~ T a r i k h ~ a l-M a d i n a h ~ a l-M u n a w w a r a h, ~ a l i h ~ B a h a s a ~ H . ~ M i f t a h u l j a n n a h ~ A z h a r y ~}$ Hasan dengan judul Beberapa Bagian dari Sejarah di Madinah,ed. II (Jeddah : Syarikah al-Madinah alMunawwarah li Tiba'ah wa al-Nasyr, 2003), h. 8.

${ }^{13}$ Badri Yatim, Sejarah Peradaban Islam Dirasah Islamiyah II, (Jakarta : PT Raja Grafindo Persada, 2007), h. 36.

${ }^{14}$ Ibid.

${ }^{15}$ Ibid.
} 
Politik Umar di masa itu adalah ingin menggabungkan semua ras Arab ke dalam satu kesatuan.

Di bidang pemerintahan, langkah pertama yang dilakukan Umar bin Khattab sebagai khalifah adalah meneruskan kebijaksanaan yang telah ditempuh Abu Bakar dalam perluasan wilayah Islam ke luar semenanjung Arabia secara besar-besaran, sehingga priode ini lebih dikenal dengan Futuhat al-Islamiyah (perluasan wilayah Islam).

Gelombang ekspansi tersebut, pertama terjadi, ibu kota Syria, Damaskus, jatuh tahun $635 \mathrm{M}$ dan setahun kemudian, setelah tentara Bizantium kalah dipertempuran Yarmuk, seluruh daerah Syria jatuh ke bawah kekuasaan Islam. Dengan memakai Syria sebagai basis, ekspansi diteruskan ke Mesir di bawah pimpinan 'Amr ibn 'Ash dan ke Irak di bawah pimpinan Sa'ad ibn Abi Waqqash, Iskandaria, ibu kota Mesir, ditaklukkan tahun 641 M. Dengan demikian, Mesir jatuh ke bawah kekuasaan Islam. Al-Qadisiyah, sebuah kota dekat Hirah di Iraq, jatuh pada tahun 637 M. Dari sana serangan dilanjutkan ke Ibu kota Persia, al-Madain yang jatuh pada tahun itu juga. Pada tahun 641 M, Mosul dapat dikuasai. Karena itu pada masa kepemimpinan Umar, wilayah kekuasaan Islam sudah meliputi Jazirah Arabia, Palestina, Syria, sebagian besar wilayah Persia, dan Mesir. ${ }^{16}$

Setelah Umar bin Khattab melakukan perluasan daerah kekuasaan Islam, beliau segera mengatur administrasi Negara dengan mencontoh administrasi pemerintahan diatur menjadi delapan wilayah propinsi : Makkah, Madinah Syria, Jazirah, Basrah, Kufah, Palestina, dan Mesir. Beberapa departemen yang dipandang perlu didirikan. Pada masanya mulai diatur dan diterbitkan system pembayaran gaji dan pajak tanah. Pengadilan didirikan dalam rangka memisahkan lembaga Yudikatif dengan lembaga eksekutif. Untuk menjadi keamanan dan ketertiban, jawatan kepolisian dibentuk. Demikian pula jawatan pekerjaan umum. ${ }^{17}$

Bersamaan dengan keberhasilan ekspansi Islam di atas, pusat kekuasaan Islam di Madinah mengalami perkembangan yang amat pesat. Khalifahan Umar telah berhasil membuat dasar-dasar bagi suatu pemerintahan yang handal untuk melayani tuntutan masyarakat baru yang terus berkembang. Umar mendirikan dewan-dewan (jawatan), membangun Baitul Mal, mencetak mata uang, membentuk kesatuan tentara untuk melindungi daerah tapal batas, mengatur gaji, mengangkat hakim-hakim dan menyelenggarakan hisbah (pengawasan) pasar mengontrol timbangan dan takaran, menjaga tata tertib dan kesusilaan dan sebagainya. ${ }^{18}$

\footnotetext{
${ }^{16}$ Harun Nasution, Islam Ditinjau dari Berbagai Aspeknya, jilid I, (Jakarta : UI Press, 1978), h. 57-58

${ }^{17}$ Syibli Nu'am , Umar yang Agung, dikutip oleh Badri Yatim, dalam Sejarah Peradaban Islam Dirasah Islamiyah II, (Jakarta : PT. Raja Grafindo Persada, 2007), h. 37.

${ }^{18}$ Ali Mufrodi, Islam di Kawasam Kebudayaan Arab, cet I (Jakarta : Logos Wacana Ilmu, 1997), h.57.
} 
Karena itu dapat dikatakan bahwa kepemimpinan Umar bin Khattab memiliki keistimewaan tersendiri, karena beliau berani dan mampuh melahirtkan beberapa kebiijakan yang bernilai positif yang dapat dimanfaatkan oleh generasi ke generasi. Selanjutnya

\section{Pembinaan Masyarakat Islam}

\section{Kehidupan social politik}

Pada masa awal pemerintahan Umar bin Khattab sebagai Khalifah, beliau melanjutkan program Abu Bakar al-Siddiq, baik yang bersifat internal maupun eksternal. Dalam urusan eksternal, Umar melakukan ekspansi ke luar Arab seperti ke Mesir, Iraq, Syiria, sampai wilayah utara Mesopotamia. Kekuatan perang Umar sangat tangguh dan sangat disegani, sehingga kekuatan pasukan kerajaan Persia yang dikenal paling kuat, dapat dikalahkan. Sedangkan untuk masalah internal, Umar dengan tegas melakukan pembenahan terhadap orang-orang yang tidak mau membayar zakat, orangorang munafik serta orang-orang murtad. Karena hal tersebut dianggap sebagai penyakit yang sangat berbahaya.

Selain menjadi pemimpin yang gagah berani, Umar juga sebagai sosok pemimpin yang mempunyai kepedulian yang tinggi terhadap kondisi sosial masyarakat. Pernah suatu ketika, Umar melakukan kunjungan ke tengah masyarakat dengan menyamar sebagai rakyat biasa. Ketika berada di sebuah desa, tiba-tiba Umar mendengar tangisan anak kecil. Kemudian Umar menanyakan kepada ibunya, kenapa anaknya menangis terus, ternyata anak tersebut kelaparan. Ibunya pura-pura masak supaya anaknya diam, padahal ibu tersebut tidak memasak apa-apa karena tidak ada yang dimasak. Melihat hal itu, Umar sangat tersentuh kemudian pergi menuju gudang makanan untuk mengambil gandum. Tatkala Umar mengangkat gandum, salah seorang pegawainya melihat, "Wahai Amirul Mukminin, biarkan aku yang mengangkat gandumnya," pinta seorang pegawai. "Tidak! biarkan aku sendiri yang mengangkatnya, apakah kamu sanggup menggantikan tanggung jawabku di hadapan Allah nanti," jawab Umar. ${ }^{19}$

Oleh karena itu, langkah yang diciptakan Umar dalam kehidupan social kemasyarakatan di atas, adalah sangat bijaksana dalam rangka menjaga kestabilan politiknya, demi menciptakan Negara yang adil makmur dan sejahtra.

\section{Pencerahan dalam Kehidupan Keagamaan \# Menggalang Kesatuan Akidah}

Kesatuan politik untuk negeri-negeri Arab adalah menjadi idaman Umar bin Khattab sejak masa pemerintahan Abu Bakar al-Siddiq. Takkala beliau memegang

\footnotetext{
${ }^{19}$ Muhammad Haekal, op, cit, h. 655-656.
} 
tampuk kekuasaan, prioritas utamanya adalah memperkukuh kesatuan dan menegakkan dasar-dasarnya. Pemikiran itu telah memberikan arah kepadanya bahwa kesatuan itu tidak akan bersih kecuali harus dibersihkan terlebih dulu dari segala cacat, yakni semua orang Arab harus bersatu dalam kesatuan tanah air dan akidah seperti halnya dalam bahasa mereka. ${ }^{20}$

Langkah pertama yang diambil oleh Umar ketika menjabat sebagai khalifah adalah, mengeluarkan kaum Nasrani Najran dari Semenanjung, dan memerintahkan Ya'la bin Umayyah supaya jangan ada orang yang terpedaya dari agamanya, dan mengeluarkan mereka yang masih berpegang pada agama mereka. Mereka diberi tanah di Irak seperti tanah mereka di Najran. Mereka harus diperlakukan dengan baik. Begitu juga terhadap orang-orang Yahudi di Khaibar dan di Fadak, mereka agar dipindahkan dari tempat-tempat mereka ke Syam dan memberi ganti rugi sesuai dengan harganya, dan jangan sampai ada yang diganggu. Dengan demikian seluruh Semenanjung itu bersih dari segala keyakinan selain Islam. Akhirnya tegaklah dasardasar kesatuan yang dimaksud oleh Amir al-Mukminin. ${ }^{21}$

Untuk memperkukuh dasar-dasar persatuan di negeri-neger Arab itu tidak cukup hanya dengan melarang ada agama lain di luar Islam, kalau diantara penduduknya masih ada diskriminasi yang akan membuat mereka merasa lebih banyak mendapat kebebasan dan lebih terhormat dari yang lain, dan kalau tidak ada persamaan sejati sebagai tanda adanya kerjasama di antara mereka. Beberapa diskriminasi itu masih dirasakan karena adanya kaum Riddah dan peperangan yang sudah berhasil ditumpas. Jika Umar memang menginginkan persatuan itu benar-benar terwujud, diskriminasi itu harus dihilangkan dengan menghilangkan penyebabnya lebih dulu. Oleh karena itu ia mencabut ketentuan di masa Abu Bakar yang melarang mereka ikut berperang di barisan Muslimin. Juga memerintahkan para tawanan Arab dikembalikan kepada keluarga-keluarga mereka dan memberikan kebebasan kembali kepada mereka, sebab ia tidak senang tawanan di kalangan Arab akan dijadikan suatu kebiasaan. Dengan demikian ia telah membuka era baru yang membuat hati semua orang Arab merasa senang, lepas dari daerah-daerah mereka masing-masing di Semenanjung itu. Mereka merasa bahwa mereka adalah satu "bangsa" dengan tujuan bersama dalam bimbingan suatu politik yang umum dan kepentingan yang utama di bawah pengawasan Amir al-Mu'minin. ${ }^{22}$

Meskipun hal tersebut tidak dilaksanakan sepenuhnya oleh Umar, namun semangat persatuan (kebangsaan) dan tolerans tetap ada karena beliau mengeluarkan orang Yahudi dan Nasrani dari lingkungan ummat Islam atas dasar menjaga stabilitas keamanan, karena kedamaian memang tidak mungkin terwujud ditengah-tengah masyarakat yang berbeda akidah, meskipun Umar tetap memperhitungkan hak-hak mereka sebagai warga Negara. Itulah sebabnya tanah mereka diperhitungkan (ada ganti rugi).

\footnotetext{
${ }^{20}$ Ibid, h. 640.

${ }^{21}$ lbid, h, 641.

${ }^{22}$ Ibid, h, 642.
} 


\section{Melahirkan Ijtihad yang Moderat}

Rasulullah saw. pernah bermimpi tentang Umar. Dalam takwilnya, beliau menyatakan bahwa Umar adalah seorang yang ahli Agama yang baik. Selain itu, Umar memiliki kemampuan berpikir kreatif dan inovatif. Hal itu terbukti dengan langkahlangkah Umar yang berani mengambil ijtihad dalam masalah furu'iyah ketika merespons persoalan yang belum ada ketetapan nasnya. Seperti "perlunya mendokumentasikan" al-Quran yang tercecer, sebab hufadz (hafiz al-Quran) banyak yang meninggal di medan perang. Maka perlu diambil langkah antisipatif dengan menugaskan Zaid untuk mengumpulkan al-Quran selama tiga tahun secara terus menerus, sehingga terkumpullah naskah al-Quran tiga puluh juz yang otentik dan orisinal. Dan setelah itu, al-Quran tersebut disimpan di rumah Hafsah, salah satu istri Nabi yang juga putri Umar. ${ }^{23}$ Meskipun al-Qur'an sekarang namanya "Mushaf Usman", tetapi gagasan awalnya berasal dari Umar, merupakan warisan intelektual Islam yang paling berharga. ${ }^{24}$

Contoh lain, Umar pernah melakukan ijtihad ketika kaum Muslimin melakukan salat sunah tarawih pada malam Ramadhan. Memang hal tersebut tidak dianjurkan ketika Rasulullah saw masih hidup, karena khawatir dianggap menjadi salat wajib karena Rasulullah saw hanya melakukannya selama tiga hari saja. Pada saat Umar melihat hal tersebut, muncul inisiatif (ijtihad) mengajak kaum Muslimin yang berada di Masjid untuk salat berjamaah. Kemudian ada salah seorang jamaah bertanya kepada Umar, "Apakah yang dilakukan Umar tidak termasuk bid'ah?" "Ni'ma al-bid'atu hadzihi" artinya sebaik-baik bid'ah adalah ini (yang kita lakukan)," jawab Umar. ${ }^{25}$

Al-Askari berkata bahwa, Umar adalah khalifah yang menamakan dirinya dengan Amirul Mukminin, dia adalah orang yang pertama kali menulis penanggalan (kalender) Islami diawali dari hijrah Rasulullah. Dia yang pertama kali mendirikan Baitul Mal, yang pertama kali memerintahkan salat tarawih secara berjamaah di bulan Ramadhan, yang pertama kali mengawasi kondisi rakyatnya di malam hari, yang pertama kali memberi hukuman kepada orang yang menghujat, yaqng pertama kali menyiksa peminum khamar dengan depan puluh deraan, yang pertama kali melarang kawin mut'ah, yang pertama kali melarang menjual ibu-ibu mantan budak yang melahirkan anak dari tuannya, yang pertama kali mengumpulkan orang untuk melakukan salat jenazah secara berjamaah dengan empat taskbir, yangf pertama kali membangun kantor-kantor administrasi, dan yang pertama kali membuat kota-kota besar. $^{26}$

Umar juga pernah melakukan keputusan yang berbeda dalam soal ghanimah (harta rampasan perang). Sebelumnya, ghanimah selalu dibagikan setelah usai perang kepada para mujahid (orang yang ikut perang). Namun Umar berani mengambil

\footnotetext{
${ }^{23}$ Ibid h. 740.

${ }^{24} \mathrm{Hj}$ Musyrifah Sunanto, Sejarah Islam Klasik Perkembangan IImu Pengetahuan Islam, , cet.I (Jakarta : Kencana, 2003), h. 23.

${ }^{25}$ Imam al-Suyutthi, Tarikh al-Khulafa ,op, cit, h. 158.

${ }^{26}$ Imam al-Suyutthi, Tarikh al-Khulafa ,op, cit, h. 128
} 
keputusan yang kontroversial, ghanimah tidak dibagikan kepada kaum Muslimin seluruhnya tetapi diberikan kepada penduduk setempat, sekalipun dia kafir namun yang dia harus membayar jizyah (pajak), maka orang tersebut disebut kafir dzimmiy, yaitu orang kafir yang taat mengikuti peraturan pemerintah Islam. Hal ini dilakukan oleh Umar dengan pertimbangan bahwa hal tersebut merupakan kebijakan yang lebih manusiawi, karena telah disesuaikan dengan keadaan. ${ }^{27}$

Sikap berani melakukan ijtihad telah dibenarkan oleh Rasulullah SAW ketika beliau bertanya kepada Muaz bin Jabal yang akan diutus ke Yaman, "Bagaimana seandainya nanti kamu menemukan persoalan baru yang belum ada ketetapan nasnya, "tanya Rasul. "Aku akan melakukan ijtihad, "jawab Muaz. Melihat hal itu, Rasulullah SAW membenarkan sikap Muaz bin Jabal. Jadi, Rasulullah SAW telah memberikan isyarat bahwa bukan termasuk bid'ah apabila melakukan ijtihad yang memiliki tujuan lebih baik bagi kemaslahatan umat. Sedangkan menambah atau mengurangi hal-hal yang berkaitan dengan sesuatu yang memiliki hukum pasti yaitu masalah ushuliyah seperti masalah akidah dan rukun Islam maka baru termasuk kriteria bid'ah. Sedangkan di luar itu, dalam masalah furu'iyah kaum Muslimin telah diberikan ruang untuk melakukan ijtihad selama tidak bertentangan dengan nas yang qath'i. ${ }^{28}$

Begitu besar jasa dan perjuangan Umar dalam membela dan menegakkan panji-panji kalimat tauhid di muka bumi sehingga jasa-jasa Umar terukir dalam sejarah Islam dengan tinta emas.

\section{Strategi Komunikasi Pemerintahan Umar bin Khattab}

Strategi Komunikasi pemerintahan Madinah di masa Umar bin Khattab adalah didasarkan pada pemerintahan Rasulullah dan masa Abu Bakar setelah itu. Dasarnya adalah syura (musyawarah). ${ }^{29}$

Rasulullah pernah bermusyawarah dengan para sahabatnya, terutama dengan Abu Bakar dan Umar, beliau berkata kepada mereka : "Demi Allah sekiranya kalian berdua sudah sepakat untuk satu persoalan, saya tidak akan pernah meninggalkan kalian dalam bermusyawarah" Karena itu, Umar menjadikan musyawarah itu sebagai dasar dalam pemerintahanya. ${ }^{30}$

Musyawarah yang berlaku waktu itu bukanlah hendak membatasi wewenang Khalifah seperti dalam sistim parlemen menurut pengertian sekarang. Kalangan pemikir yang memberikan pendapat kepada khalifah tidaklah pula berhak memaksakan pendapat mereka kepadanya. Dengan musyawarah itu kekuasan penuh tetap di tangan Khalifah. Dia bertanggung jawab kepada Allah, kepada dirinya sendiri dan kepada ummat yang telah mengangkatnya. Kalau dia sampai melampaui hak itu

\footnotetext{
${ }^{27}$ Muhammad Haikal, op, cit, h. 221.

${ }^{28}$ Ibnu Kasir, al-Hakam al-Hafidz 'Imad al-Din Abi al-Fida Ismail Ibn al-Kasir, al-Bidayah wa al-Nihayah, juz 7 (Beirut-Lubnan : Dar Ihya al-Turas, t.th), h. 92.

${ }^{29}$,Muhammad Husain Haekal, op, cit, 645

${ }^{30}$ Muhammad Husain Haekal, op, cit, h. 646.
} 
dan melanggar ketentuan Allah dan Rasul-Nya, dan perhitungan dengan Allah dan dengan dirinya sudah tidak pula dapat menahannya, maka ummatlah yang akan meluruskannya dengan mata pedang.

Pada musyawarah itu, Umar sering mengajak orang banyak. Ia mengajak orang ke Mesjid di Madinah, atau mengajak mereka dalam salat berjama'ah di mana saja mereka berada, kemudian ia menyampaikan masalah yang hendak dibahas bersama itu dan menawarkan kepada siapa saja yang ingin memberikan pendapat. Bila ia menghadapi masalah yang begitu pelik ia mengundang anak-anak muda untuk dimintai pendapat, karena ketajaman pikiran mereka. Kalau suatu masalah dari sidang umum itu sudah dapat dipecahkan, maka pelaksanaannya diputuskan, Sebaliknya, kalau ada masalah yang belum jelas, dikembalikan kepada staf khususnya, meminta pendapat mereka dan berdiskusi dengan mereka sampai ia merasa puas bahwa apa yang diyakininya itu benar. ${ }^{32}$ Ini berarti bahwa Umar di satu sisi sebagai khalifah di sisi lain sebagai rakyat, artinya jabatan kekhalifahan Umar tidak dijadikan sebagai alat untuk berkuasa penuh. Idealnya setiap penguasa atau pemimpin negara dan lainlainnya, mengambil contoh dan teladan terhadap kepemimpinan Umar yang sederhana dan meyakinkan.

Semangat Umar bin Khattab sejak awal sudah merancang negara Islam modern dan merumuskan banyak sistim dan dasar-dasar pemerintahan, administrasi dan keuangan yang bersumber dari ajaran-ajaran Islam. Beliau membangun asramaasrama tentara yang setelah itu berubah menjadi kota-kota yang meninggikan menara ilmu pengetahuan seperti Kufah, Basrah dan Fustat. Umar membentuk badan Pengawas Keuangan dan menyelenggarakan sensual kaum Muslimin serta memberi bantuan keuangan kepada mereka sehingga beliau disenangi masyarakat. Mereka menyambut baik kebijakan-kebijakan Umar. Kemana Umar pergi, mereka bergabung kebawah panjinya dan mereka menikmati keadilan, kejujuran dan kelembutannnya. ${ }^{33^{\circ}}$

Karena itu, Khalifah Umar berhasil meletakkan dasar-dasar bagi suatu pemerintahan yang handal untuk melayani tuntutan masyarakat baru yang terus berkembang. Umar mendirikan dewan-dewan (jawatan), membangun Baitu Mall, mencetak mata uang, membentuk kesatuan tentara untuk melindungi daerah tapal batas, mengatur gaji, mengangkat hakim-hakim dan menyelenggarakan hisbah (pengawasan pasar, mengontrol timbangan dan takaran, menjaga tata tertib dan kesusilaan dan sebagainya seperti yang disebutkan sebelumnya..

Umar memerintah selama sepuluh tahun (13-23 H/634-644 M). Dan menjelang akhir hayatnya, Umar memikirkan penggantinya meskipun tidak seperti apa yang dilakukan oleh Abu Bakar. Dia menunjuk enam orang sahabat dan meminta kepada

${ }^{31}$ Ibid, h, 647.

${ }^{32}$ Ali Mufrodi, Islam di Kawasan Kebudayaan Arab, cet I (Jakarta : 1417 H/1997 M), h. 57.

${ }^{33}$ Ali Hafidh, Fushul min Tarikh al-Madiah al-Munawwarah, diterjemahkan oleh H. Miftahuljannah Azhari Hasan, MA, dengan judul Beberapa Bagian dari Sejarah Madinah. (Jeddah : Syarikah al-Madinah alMunawwara li Tiba'ah wa al-Nasyr, 1998), h. 9 
mereka untuk memilih salah seorang diantaranya menjadi khalifah. Enam orang tersebut adalah, Usman, Ali, Thalha, Zubair, Sa'ad ibn Abi Waqqas, dan Abdurrahman ibn 'Auf..'

Kebijakan yang dilakukan Umar dalam menjaga stabilitas politik adalah membentuk tim 6 di atas dengan harapan merekalah yang nantinya akan memilih siapa diantara mereka yang pantas melanjutkan kepemimpinan ini dengan mengutamakan musyawarah di atas segalanya. Dan hal inilah salah satu hal yang membedakan Umar dengan Abu Bakar, di mana Abu Bakar menggunakan wasiat kepada Umar, tanpa membentuk tim.

Akhirnya, pada hari Rabu tanggal 4 Zulhijjah tahun ke-23 H, ketika Umar keluar dari rumahnya hendak mengimani salat subuh tiba-tiba ditikam oleh Abu Lu'luah. yaitu orang dari Persia beragama Nasrani, yang pernah menjadi tawanan perang. Abu Lu'luah merupakan orang suruhan bekas Raja Persia yang sakit hati karena kekuasaannya direbut oleh Umar. Abu Lu'luah berhasil masuk ke dalam Masjid dan menyusup di antara barisan jamaah salat subuh pada shaf (baris) pertama tepat di belakang Umar, lalu menikam ulu hati Umar hingga meninggal. ${ }^{35}$ Dan setelah Umar ${ }^{36}$ wafat, tim ini bermusyawarah dan berhasil menunjuk Usman sebagai khalifah, melalui persaingan ketat dengan Ali bin Abi Thalib

\section{KESIMPULAN}

Berdasarkan dari uraian di atas, maka penulis dapat menyimpulkan beberapa hal sebagai berikut :

\footnotetext{
${ }^{34}$ Badri Yatim, op, cit, h. 38.

${ }^{35}$ Muhammad Haikal, op, cit, h. 773-774.
}

${ }^{36}$ Mengenai kematian Umar, para ahli sejarah menyebutkan kemungkinan adanya permusuhan yang meningkat antara bangsa Persia dengan Umar ibn al-Khattab. Permusuhan itu antara lain disebabkan oleh beberapa faktor :Pertama, pada masa Umar, Negeri Persia dibuka oleh Islam dan bangsa Arab masuk ke daerah itu. Kemungkinan hal itu dianggap bangsa Persia sebagai penjajahan, sedangkan Persia adalah satu negeri besar yang tidak pernah dijajah atau ditundukkan oleh siapapun. Disamping itu bangsa Persia pun merasa dirinya lebih maju dari pada semenanngjung Arabia dan bangsa Arab, dan sejarah memang membuktikannya. Kedua, banyak pembesar Persia seperti raja, menteri-menteri dan lain-lainnya yang kehilangan jabatan. Hal itu menimbulkan rasa kesal dan tidak puas, apalagi sebelumnya kekuasaan mereka sangat luas dan memiliki banyak hamba sahaya dan pengikut. Ketiga, rasa dendam atas perbuatan dari agama yang berlainan bangsa yang tidak seimbang menurut pendapat mereka dan dari seorang khalifah yang mereka anggapsepi, maka pembunuhan terhadap 'Umar adalah usaha membalas dendam memuaskan hati, membunuh mati seorang yang dianggap memegang peranan dalam penaklukan Persia. Keempat, Islam yang baru memasuki Negara itu belum dapat menghilangkan sekaligus kecongkakan Persia sebagai "Salah satu dari kedua Raksasa Dunia" di saat itu.. Lihat Fuad Mohd Fachruddin, Perkembangan Kebudayaan Islam, cet I, (Jakarta : Bulan Bintang, 1985), h. 22. 
Pertama, Situasi masyarakat dan negara pada masa perkembangan Islam memiliki cirihas masing-masing yaitu, pada masa Rasulullah penekanannya adalah dakwah kepada akidah tauhid selama 13 tahun di Mekkah, hukum, ibadah, mu'amalah, social budaya dan politik di Madinah selama 10 tahun. Abu Bakar banyak melakukan peperangan melawan orang-orang murtad dan orang-orang yang enggan membayar zakat atau jizyah, dan Umar sendiri memperbanyak ekspansi keluar demi memperluas jaringan ummat Islam sebagai kebanggaan kita.

Kedua, Dalam upaya mewujudkan suatu pemerintahan yang bersih, jujur, adil, dan makmur, diperlukan langka-langka strategi sebagi indikator dalam rangka menggalang kesatuan dan persatuan, baik dalam bidang social budaya, politik dan keagamaan, tanpa menapikan perlunya ijtihad dalam hal-hal yang dianggap dapat memberi motivasi dan solusi terhadap problema keummatan.

Ketiga, Situasi politik pada masa pemerintahan Umar bin Khattab adalah terkendali di bawah panji al-Qur'an dan Hadis Sistim demokrasi dan musyawarah adalah priorotas utama dalam pengambilan suatu kebijakan. Wallahu a'lam 
Al-Qur'an al-Karim

\section{DAFTAR PUSTAKA}

Dewan Ensiklopedi Islam, Ensiklopedi Islam, jilid 5, cet.9 ( Jakarta : Ichtiar Baru Van Houve, 2001

El-Awa Muhamed S. On the Political System of the Islamic State, diterjemahkan oleh Mohd Isa Che Dir, dengan judul Sistim Politik Negara Islam, (Kuala Lumpur : Dewan Pustakan dan Bahasa, 1991

Fachruddin, Fuad Mohd. Perkembangan Kebudayaan Islam, cet I, Jakarta : Bulan Bintang, 1985.

Hafidz, 'Ali. Fusul min Tarikh al-Madinah al-Munawwarah, alih Bahasa H. Miftahuljannah Azhary Hasan dengan judul Beberapa Bagian dari Sejarah di Madinah,ed. II (Jeddah : Syarikah al-Madinah al-Munawwarah li Tiba'ah wa al-Nasyr, 1998

Haekal, Muhammad Husain. al-Faruq Umar, diterjemahkan oleh Ali Audah dengan judul Umar bin Khattab Sebuah Telaah Mendalam Tentang Pertumbuhan Islam dan Kedaulatannya Masa itu, cet. 9, (Bogor : Pustaka Litera AntarNusa, 2008

Yatim, Badri. Sejarah Peradaban Islam Dirasah Islamiyah II, (Jakarta : PT Raja Grafindo Persada, 2007.

Kasir, Ibnu. al-Hakam al-Hafidz 'Imad al-Din Abi al-Fida Ismail Ibn al-Kasir, al-Bidayah wa al-Nihayah, juz 7 (Beirut-Lubnan : Dar Ihya al-Turas, t.th

Mujamma' Khadim al-Haramain asy-Syarifain al-Malik Fahd li al-Tiba'at al-Mushaf asySyarif, Al-Qur'an dan Terjemahnya, (Madinah al-Munawarah : al-Malik Fahd li alTiba'at al-Mushaf asy-Syarif $1412 \mathrm{H}$

Mufrodi, Ali. Islam di Kawasan Kebudayaan Arab, cet I, Jakarta : 1417 H/1997 M

Nasution, Harun. Islam Ditinjau dari Berbagai Aspeknya, jilid I, (Jakarta : UI Press, 1978

Nu'am, Syibli, Umar yang Agung, dikutip oleh Badri Yatim, dalam Sejarah Peradaban Islam Dirasah Islamiyah II, (Jakarta : PT. Raja Grafindo Persada, 2007

Syalabi, Syekh Muhammad Mustafah. al-Madkhal fi al-Tarikh al-Ta'rif bi al-Fiqh al-Isami (Beirut : t.pt, 1968.

Syalabi, Ahmad. Mausu'ah al-Tarikh al-Islamiy wa al-Hadarah al-Islamiyah, al-Qahira : Maktabah al-Nahdah al-Misriyah, 1983. 
Al-Suyuty, Hafidz Jalaluddin. Tarikh al-Khulafa, (Beirut-Lubnan : Dar al-Fikr, t.th.

Sjadzali, Munawir. Islam dan Tata Negara Ajaran, Sejarah dan Pemikiran, ed. 5 (Jakarta : Universitas Indonesia Press,,199.

Sunanto, Musyrifah. Sejarah Islam Klasik Perkembangan Ilmu Pengetahuan Islam, , cet.I (Jakarta : Kencana, 2003

Syihab, M. Quraisy. Tafsir al-Misbah : Pesan, Kesan, dan Keserasian al-Qur'an, vol. 12, cet II, (Jakarta : Lentera Hti, 2002

Thontowi, Jawahir. Pesan Perdamaian Islam, cet, I, Yogyakarta : Pustaka Pelajar, 2001

Al-Usairy, Ahmad. al-Tarikh al-Islamiy, diterjemahkan oleh Samson Rahman dengan judul Sejarah Islam Sejak Zaman Nabi Adam Hingga Abad XX, cet.6 (Jakarta : Media Eka Sarana, 1429 H/2008 M 